\title{
Czy idea tak zwanej wtórnej legalności się broni?
}

\author{
JAROSŁAW MAJEWSKI \\ Katedra Prawa Karnego \\ Uniwersytet Kardynała Stefana Wyszyńskiego w Warszawie
}

I. Analizując bardzo bogaty i pod każdym względem wyróżniający się dorobek naukowy Profesora Tomasza Kaczmarka, łatwo dostrzec, że zawsze najwięcej uwagi poświęcał On zagadnieniom z zakresu teorii prawa karnego; trudno byłoby znaleźć w tej sferze jakąś istotniejszą kwestię, odnośnie do której Dostojny Jubilat nie zająłby dotąd stanowiska. Wypowiadał się, naturalnie, również na temat określony w tytule tego opracowania ${ }^{1}$, które dedykuję Profesorowi Tomaszowi Kaczmarkowi, pragnąc tym skromnym sposobem wyrazić swoje uznanie dla zasług, jakie położył On dla rozwoju polskiej myśli karnistycznej.

II. Zgodnie z tym, co zapowiada tytuł opracowania, celem prowadzonych rozważań jest krytyczna analiza dość popularnej w naszym piśmiennictwie karnistycznym idei tak zwanej wtórnej legalności, w szczególności zbadanie, czy dobrze współgra ona z podstawowymi założeniami o systemie prawa, normach prawnych itp. przyjmowanymi w naszej kulturze prawnej, a jeżeli nie — to z którymi z nich się kłóci, jak również sprawdzenie, w jakim stopniu odwoływanie się do tej idei w analizach karnistycznych jest użyteczne oraz czy cena, jaką przychodzi za to płacić, nie jest zbyt wygórowana. Kwestia zasadności wyróżniania tak zwanej legalności pierwotnej oraz tak zwanej legalności wtórnej wydaje się warta podjęcia tym bardziej, że w ostatnich latach stała się ona u nas przedmiotem bardzo ożywionej dyskusji naukowej, której katalizatorem było IV Bielańskie Kolokwium Karnistyczne poświęcone problematyce okoliczności wyłączających bezprawność czynu².

${ }^{1}$ Zob. zwłaszcza T. Kaczmarek, O tzw. okolicznościach „wyłaczajacych” bezprawność czynu, PiP 2008, z. 10, s. 21 n.; idem, O kontratypach raz jeszcze, PiP 2009, z. 7, s. 91 n.

2 Zob. pokłosie tej konferencji (w tym zapis dyskusji) - Okoliczności wyłaczające bezprawność czynu, red. J. Majewski, Toruń 2008; a także T. Kaczmarek, O tzw. okolicznościach „,wyłaczajacych”...; idem, O kontratypach...; J. Giezek, „Zezwolenie” na naruszenie dobra praw- 
III. Myśl, że zachowania się zgodne z prawem dobrze jest, czy wręcz koniecznie należy, dzielić na „legalne pierwotnie” oraz „legalne wtórnie”, promowana w polskiej karnistyce bardzo konsekwentnie od wielu lat przez A. Zolla ${ }^{3}$, ściśle wiąże się z problematyką tak zwanych okoliczności wyłączających bezprawność czynu pojmowaną jako kategoria jednolita, „nierozszczepialna”, słowem: okoliczności wyłączających „wszelką bezprawność” czynu, zwanych często również „kontratypami”"4, albowiem właśnie w jej obrębie zwolennicy omawianego podziału używają etykiety „wtórna legalność” dla objaśnienia statusu zachowań mieszczących się w ramach okoliczności wyłączających wszelką bezprawność (dalej będę nazywał je krócej „,zachowaniami się kontratypowymi” lub „czynami kontratypowymi”), mianowicie na oznaczenie stosunku, w jakim owe zachowania się pozostają — z jednej strony — do systemu prawa jako całości, z drugiej zaś — do poszczególnych norm sankcjonowanych, należących do tego systemu. Wymaga to krótkiego przypomnienia, w jaki sposób, w jakim kontekście i w jakim celu kategoria okoliczności wyłączających bezprawność czynu jest używana w procesie analizy karnistycznej ${ }^{5}$.

Do kategorii okoliczności wyłączających (wszelką) bezprawność odwołujemy się, gdy chcemy uzasadnić twierdzenie (ocenę), iż określone zachowanie się człowieka nie jest bezprawne (w sensie: jest zgodne z prawem) i z tego względu, choć podpada pod rodzajowy opis czynu zabronionego, podany w odpowiednim przepisie typizującym, nie może być podstawą odpowiedzialności karnej jego sprawcy. Jak wiadomo - jednym z powszechnie aprobowanych założeń analizy karnistycznej od dawna jest teza, że podstawą odpowiedzialności karnej mogą być jedynie takie zachowania się, które są niezgodne z prawem, że karalne może

nego - negatywne znamię typu czynu zabronionego czy okoliczność kontratypowa, [w:] Aktualne problemy prawa karnego. Księga pamiątkowa z okazji jubileuszu 70. Urodzin Profesora Andrzeja J. Szwarca, red. Ł. Pohl, Poznań 2009, s. 131 n.; A. Zoll, W sprawie kontratypów, PiP 2009, z. 4; idem, Czy jest uzasadnione wyróżnianie pierwotnej i wtórnej legalności?, [w:] W poszukiwaniu dobra wspólnego. Księga jubileuszowa Profesora Macieja Zielińskiego, red. A. Chodun, S. Czepita, Szczecin 2010, s. 357 n.

3 Zob. zwłaszcza A. Zoll, Okoliczności wyłaczające bezprawność czynu, Warszawa 1982, s. 86 n. oraz passim; idem, Odpowiedzialność lekarza za niepowodzenie w leczeniu, Warszawa 1988, s. 6 n.; idem, O normie z punktu widzenia prawa karnego, KSP 23, 1990, s. 90-91, 94; idem, [w:] Kodeks karny. Część ogólna, t. 1. Komentarz do art. 1-52, red. W. Wróbel, A. Zoll, Warszawa 2016, s. 536-537, tezy 8-10 uwag wprowadzających do rozdz. III.

${ }^{4} \mathrm{~W}$ tym opracowaniu, podobnie jak w innych swych pracach, terminy „okoliczność wyłączająca (wszelką) bezprawność czynu” oraz „kontratyp” traktuję jako zamienne (synonimiczne).

5 Funkcję kategorii okoliczności wyłączających bezprawność jako narzędzia analizy karnistycznej omawiam szeroko w monografii Okoliczności wyłączające bezprawność czynu a znamiona subiektywne, Warszawa 2013, s. 19 n. Poniższe uwagi na ten temat zasadzają się na poczynionych tam ustaleniach. 
być tylko to, co bezprawne ${ }^{6}$, którą rozwija się często wskazaniem, że nie mogą być w związku z tym karalne zachowania się przez prawo dozwolone ani tym bardziej nakazane. Pomimo tego założenia, a w pewnym sensie nawet wbrew niemu, z różnych ważkich względów, przede wszystkim praktycznych, wśród których prym wiedzie wzgląd na potrzebę zwięzłości i komunikatywności tekstu prawnego, przepisy typizujące nie są jednak na ogół redagowane w taki sposób, że zawarty w nich rodzajowy opis czynu zabronionego obejmuje wyłącznie zachowania się bezprawne ${ }^{7}$. Toteż interpretator tekstu prawnego ma typowo do czynienia z sytuacją, w której rodzajowy opis czynu zabronionego, zawarty w przepisie typizującym, niejako „wylewa” się na określonych odcinkach poza (założone) granice kryminalizacji, „wycinając” z uniwersum możliwych czynów ludzkich więcej niż trzeba. Jednym z jego zadań jest właśnie dokładne zinwentaryzowanie odcinków, na których do tego doszło, i stosowne ich wycyzelowanie — dzięki odpowiednim zabiegom interpretacyjnym - w taki sposób, by wszelkie sytuacje, w których zachowania się odpowiadające owemu opisowi rodzajowemu nie są bezprawne, pozostały poza zakresem zastosowania wykładanego przepisu typizującego. To właśnie w ramach tej procedury, która prowadzi do zawężania zakresu zastosowania wykładanego przepisu typizującego (jeżeli brać za punkt wyjścia językową „pojemność" rodzajowego opisu czynu zabronionego w nim zawartego), karniści posługują się okolicznościami wyłączającymi bezprawność czynu jako „korektorami nieuniknionych niedociągnięć w powiązaniu typów czynów z ich społecznie

${ }^{6}$ Bezprawność jako element struktury przestępstwa pojawia się już klasycznym, Belingowym trójelementowym ujęciu tej struktury. Warto przytoczyć w tym miejscu celną i wciąż aktualną wypowiedź W. Makowskiego sprzed prawie 100 lat: „Cechą działania przestępnego jest jego bezprawność. [...] kiedy chodzi o cechę bezprawności działania przestępnego, nie można zapominać, że oprócz wtórnej ustawy karnej podstawę do oceny bezprawności stanowić musi ta norma zasadnicza, która jest przedmiotem ochrony przez ustawę karną. Okoliczność ta nabiera znaczenia wówczas, kiedy działanie, niezgodne wprawdzie z nakazem lub zakazem ustawy karnej [...] nie gwałci jednak normy zasadniczej, nie zagraża interesowi, przez ustawę karną ochranianemu, przeciwnie jest z nim zgodne, albo też służy innym interesom społecznym — wyższego rzędu. W tym wypadku ustawa karna jako wtórna nie może stanowić decydującego probierza i musi ustąpić na plan drugi wobec probierza innego, wynikającego z treści i charakteru interesów i norm podstawowych. Nawet wówczas, kiedy ustawa karna jest sama źródłem normy, powołuje ją ona do istnienia w interesie ogólnym współżycia społecznego i organizacji państwowej, nie zaś samą dla siebie. Tylko wtedy zatem działanie jest bezprawne, jeżeli, przeciwstawiając się ustawie karnej, dotyka zarazem tego, co stanowi przedmiot jej ochrony z punktu widzenia ogólnych zadań społecznych, którym służy oprócz ustawy karnej także szereg innych urządzeń i norm" (Prawo karne. Część ogólna. Wykład porównawczy prawa karnego austrjackiego, niemieckiego i rosyjskiego obowiąującego w Polsce, Warszawa 1920, s. 163-165). Więcej na temat bezprawności jako warunku przestępności - zob. Z. Jędrzejewski, Bezprawność jako element przestępności czynu. Studium na temat struktury przestępstwa, Warszawa 2009.

7 Więcej o powodach, dla których w systemach prawnych typu kontynentalnego (jak nasz) treść przepisów typizujących nie oddaje wiernie dokładnego przebiegu granic kryminalizacji zob. J. Majewski, Okoliczności wyłączające bezprawność czynu..., s. 19-25. 
ujemną wartością"8. Na przykład, w ten sposób „doszlifujemy” — z powołaniem się na odpowiedni kontratyp, mianowicie ,kontratyp działania w ramach obowiązków służbowych" - zakres zastosowania art. 189 k.k. do takiego kształtu, że nie będzie on obejmował czynu funkcjonariusza policji, który w toku wykonywania obowiązków służbowych, w czasie patrolu, zatrzymuje sprawcę włamującego się do sklepu na gorącym uczynku przestępstwa. Taki czyn podpada wprawdzie pod rodzajowy opis czynu zabronionego, podany w art. 189 k.k., gdyż ewidentnie przedstawia się jako ,(umyślne) pozbawienie drugiej osoby wolności”, lecz w okolicznościach, w jakich został dokonany, nie jest bezprawny, lecz zgodny z prawem, skoro — co jest równie ewidentne — stanowi wykonanie obowiązku służbowego.

Streszczając, można stwierdzić, że kategoria okoliczności wyłączających bezprawność jest wykorzystywana jako instrument uadekwatniania zakresu zastosowania przepisu typizującego — i na tym polega jej funkcja ${ }^{9}$. W zależności od warsztatu danego interpretatora, przyjmowanych przezeń założeń metodologicznych oraz stosowanej konwencji terminologicznej kategoria okoliczności wyłączających bezprawność czynu jest albo jedynym narzędziem używanym w ramach analizy karnistycznej w zakresie rozważanych wykładniowych zabiegów uadekwatniających, albo jednym z większej liczby takich narzędzi. Mówiąc językiem bardziej plastycznym — jedni pokrywają konstrukcjami poszczególnych kontratypów całą wolną przestrzeń między granicami wyznaczonymi przez rodzajowy opis czynu zabronionego, podany w przepisie typizującym, a granicami klasy tych zachowań się, które nie tylko podpadają pod ten opis, lecz zarazem są bezprawne, inni zaś tylko pewną określoną część tej przestrzeni. Z tym pierwszym podejściem można się spotkać zwłaszcza w dawniejszym piśmiennictwie karnistycznym. Przez cały okres swej długiej i płodnej twórczości prezentował je konsekwentnie na przykład W. Wolter ${ }^{10}$, który przyjmował po prostu, że to, czego z pola zachowań się podpadających pod rodzajowy opis czynu zabronionego podany w przepisie typi-

8 W. Wolter, Funkcja błędu w prawie karnym, Warszawa 1965, s. 59.

9 W podobnym kierunku W. Wróbel, Konstrukcja kontratypu jako sposób uadekwatniania treści normy sankcjonowanej i sankcjonujacej w procesie wykładni prawa karnego, [w:] W poszukiwaniu dobra wspólnego..., zwłaszcza s. $373 \mathrm{n}$.

10 Por. na przykład jedną ze świadczących o tym wypowiedzi powołanego autora na temat genezy kontratypów: „ten sam czyn, jeżeli chodzi o jego ogólną charakterystykę może być w pewnym kontekście społecznym wolny od społecznie ujemnej oceny i jest rzeczą wykluczoną ustawić pewien typ czynu pozytywnie tak, by on chwytał wyłącznie zdarzenia społecznie niebezpieczne. To zaś znaczy, że konieczne powiązanie czynu typizowanego ze społecznie ujemną oceną możliwe jest jedynie przez zanegowanie takich kontekstów społecznych, które takiemu czynowi odbierają ujemny społecznie charakter. W ten sposób powstają kontyratypy [podkr. - J.M.], same dla siebie nie mające żadnego sensu, a nabierające znaczenia jedynie jako korektory nieuniknionych niedociągnięć w powiązaniu typów czynów z ich społecznie ujemną wartością. Mogą one wystąpić w związku z jakimś szczególnym typem przestępnym czynu, mogą również odnosić się do całych grup typów, a wtedy przechodzą one do części ogólnej prawa karnego" (W. Wolter, op. cit., s. 58-59). 
zującym, lecz niebezprawnych, nie pokrywają zakresy kontratypów ustawowych, muszą pokrywać zakresy kontratypów pozaustawowych. Współcześnie instrumentarium środków służących uadekwatnianiu zakresu zastosowania przepisów typizujących w rozważanym zakresie, stosowane w analizach karnistycznych, jest przeważnie bardziej rozbudowane i obok okoliczności wyłączających bezprawność czynu obejmuje takie kategorie, jak kategoria braku zagrożenia dobra prawnego, którego ochronie ma służyć ustanowienie rozpatrywanego przepisu typizującego, braku naruszenia reguły postępowania $\mathrm{z}$ tym dobrem $\mathrm{w}$ obrocie społecznym, braku koniecznego związku z celem ochronnym normy itp. Kto korzysta z takiego bogatszego, bardziej zróżnicowanego zestawu rzeczonych środków, najczęściej - kierując się kryterium polecanym przez A. Zolla ${ }^{11}$ — kategorię okoliczności wyłączających bezprawność czynu rezerwuje dla wypadków, kiedy zachodzi tak lub inaczej pojmowana kolizja (konflikt) co najmniej dwóch dóbr prawnych i wynikająca stąd konieczność poświęcenia (zniszczenia, narażenia na niebezpieczeństwo) jednego $\mathrm{z}$ tych dóbr po to, aby można było uratować któreś z pozostałych.

IV. Gdzie tu miejsce - mógłby ktoś spytać - dla podziału zachowań się zgodnych z prawem na legalne „pierwotnie” oraz legalne „wtórnie? Robi się ono, kiedy ustalenie, że kategoria okoliczności wyłączających bezprawność jest wykorzystywana jako instrument uadekwatniania zakresu zastosowania przepisu typizującego, próbuje się przełożyć na język właściwy dla rozważań o normach prawnych zawartych w przepisach typizujących i wyinterpretowywanych z tych przepisów $^{12}$, a jak wiadomo - coraz częściej kategoria normy prawnej staje się w polskiej nauce prawa karnego jednym z najważniejszych narzędzi analizy karnistycznej ${ }^{13}$. Można, naturalnie, posłużyć się tu bezpiecznym stwierdzeniem, iż rzeczona kategoria jest wykorzystywana jako instrument uadekwatniania granic zakresowych norm prawnych zawartych w przepisach typizujących ${ }^{14}$, lecz ze względu na zbytnią ogólnikowość mało kto się nim zadowoli, albowiem trzeba

11 Por. A. Zoll, Okoliczności wyłaczające bezprawność..., s. $101 \mathrm{n}$.

12 Zob. na przykład jeden z możliwych modeli odtwarzania norm prawnych z przepisów prawnych, jaki przedstawił M. Zieliński w pracy Interpretacja jako proces dekodowania tekstu aktu prawnego, Poznań 1972.

13 Por. J. Majewski [w:] System Prawa Karnego, t. 2. Źródła prawa karnego, red. T. Bojarski, Warszawa 2011, s. 459-461. Do rozróżnienia między przepisem prawnym oraz normą prawną odwołuje się w swych pracach między innymi Jubilat. Należy ono również do podstawowych założeń analiz prowadzonych współcześnie w obrębie tak zwanej krakowskiej szkoły prawa karnego, do której zalicza się również autor tych słów.

14 Mówiąc tu i dalej, że określona norma (sankcjonująca, sankcjonowana, kompetencyjna) jest „zawarta” w jakimś przepisie typizującym, posługuję się pewnym uproszczeniem. Ściśle biorąc, chodzi o to, że dany przepis typizujący jest tak zwanym przepisem zrębowym dla rzeczonej normy. 
pamiętać, że z przepisów prawa karnego odtwarzane bywają struktury normatywne różnego rodzaju ${ }^{15}$; przy czym sam sposób pojmowania istoty tych struktur w piśmiennictwie karnistycznym jest niespecyficzny i nawiązuje wprost do stosownych ustaleń ogólnego prawoznawstwa. Jeśli chodzi o szczególnie nas tu interesujące przepisy typizujące, to doktryna prawa karnego w Polsce zgodnie przyjmuje, że zawierają one normy sankcjonujące, prawie zgodnie — że także normy sankcjonowane ${ }^{16}$, często — że również normy kompetencyjne ${ }^{17}$ zwane też niekiedy „normami uprawniającymi”"18. W związku z tym prędzej czy później musi się wyłonić pytanie, o uadekwatnieniu zakresu jakich to norm mówimy: (wyłącznie) sankcjonujących albo (tylko) kompetencyjnych czy również sankcjonowanych ${ }^{19}$. Udzielając odpowiedzi na to właśnie pytanie, promotorzy dzielenia zachowań się zgodnych z prawem na „legalne pierwotnie” i „legalne wtórnie” odwołują się do idei wtórnej legalności.

Jakkolwiek autorzy posługujący się kategorią okoliczności wyłączających wszelką bezprawność czynu jako pewną figurą interpretacyjną zgodnie przyjmują, że czyn kontratypowy nie może być podstawą odpowiedzialności karnej, gdyż w ogólności jest zgodny z prawem ${ }^{20}$, modelują ją na dwa różne sposoby — albo jako podstawę zawężenia odpowiedniej normy sankcjonowanej, albo jako podstawę usprawiedliwienia przekroczenia owej normy. Według pierwszego z tych

15 Zob. J. Majewski [w:] System Prawa Karnego, t. 2, s. 459 n.

16 Spośród reprezentantów polskiej nauki prawa karnego jedynie A. Zoll wprost zakwestionował twierdzenie, że przepisy prawa karnego kodują również normy sankcjonowane. Zdaniem tego autora: „Przepis prawa karnego wypowiada [...] wprost jedynie normę sankcjonującą zachowanie określone w tym przepisie i ta norma, ściśle rzecz biorąc, może być jedynie określana jako norma prawa karnego. Wbrew temu, co się powszechnie twierdzi, ten, kto zabija człowieka, nie narusza normy prawa karnego, a jedynie swoim zachowaniem stwarza przesłanki do zaktualizowania się powinności stanowiącej istotę tej normy. Ten, kto zabija człowieka, narusza normę »nie zabijaj«, ale nie jest to już norma, w ścisłym tego słowa znaczeniu, prawnokarna. Sankcja w postaci kary sądowej nie jest żadną częścią składową tej normy. Normę »nie zabijaj człowieka« należy nazywać normą sankcjonowaną" (O normie z punktu widzenia ..., s. 71).

17 Por. na przykład M. Tarnawski, Zagadnienia jedności i wielości przestępstw, Poznań 1977, s. 177 n.; K. Buchała, Prawo karne materialne, Warszawa 1989, s. 100-101; C. Gofroń, Problematyka ogólna normy prawnokarnej, [w:] Problemy ewolucji prawa karnego, red. T. Bojarski, Lublin 1990, s. 14; W. Wróbel, Zmiana normatywna i zasady intertemporalne w prawie karnym, Kraków 2003, s. 29-31.

18 Niektórzy autorzy terminy „norma sankcjonująca” oraz „norma kompetencyjna” traktują jako synonimiczne. Tak na przykład J. Giezek, [w:] Prawo karne materialne. Część ogólna i szczególna, red. M. Bojarski, Warszawa 2007, s. 56. Por. też. W. Wróbel, A. Zoll, Polskie prawo karne. Część ogólna, Kraków 2010, s. 102-103.

19 Zob. więcej J. Majewski [w:] System Prawa Karnego, t. 2, s. 459-461 oraz podane tam objaśnienia terminów „norma sankcjonująca”, „,norma sankcjonowana”, „,norma kompetencyjna”.

20 Stąd wyraz „wyłączająca” w nazwie „okoliczność wyłączająca bezprawność czynu” uważa się za mało fortunny, gdyż może sugerować, że czyn kontratypowy jest pierwotnie (w jakiś sposób) bezprawny, a dopiero następczo cechę tę traci w trakcie operacji jej „wyłączania”. Podnosi to między innymi Jubilat. Por. T. Kaczmarek, O tzw. okolicznościach „,wyłączających”..., s. 24-25. 
rozwiązań czyn popełniony w ramach kontratypu nie jest bezprawny, gdyż po prostu nie przekracza normy sankcjonowanej zawartej w danym przepisie typizującym (ani żadnej innej normy należącej do danego systemu prawa) ${ }^{21}$. Z kolei według drugiego ze wspomnianych rozwiązań czyn kontratypowy stanowi przekroczenie normy sankcjonowanej, a jako zgodny z prawem należy ostatecznie kwalifikować go dlatego, że przekroczenie owej normy jest „usprawiedliwione” przez racje, które doprowadziły do ustanowienia wchodzącego w danym wypadku w grę kontratypu ${ }^{22}$. Tak właśnie widzą funkcję okoliczności wyłączających wszelką bezprawność czynu zwolennicy „,rozwarstwiania” legalności na „pierwotną” oraz „wtórną”, a sama dystynkcja służy im do lepszego objaśnienia statusu zachowania się kontratypowego, mianowicie do wyrażania ich przekonania, że zachowania się kontratypowe — w przeciwieństwie do pozostałych zachowań się zgodnych z prawem, w tym innych niż kontratypowe niebezprawnych zachowań się, podpadających pod rodzajowy opis czynu zabronionego, zawarty w przepisie typizującym (zachowań się, które nie stwarzają żadnego zagrożenia dobra prawnego stanowiącego przedmiot ochrony przepisu typizującego, nie naruszają reguł postępowania z tym dobrem w obrocie społecznym, nie mieszczą się w zakresie wyznaczonym przez cel ochronny normy itp.) — stanowią przekroczenie właściwej normy sankcjonowanej, przekroczenie legalne, lecz jednak przekroczenie. Zachowania się zgodne z prawem inne niż kontratypowe, jako nieprzekraczające żadnej normy sankcjonowanej, są według tego ujęcia legalne jakby z natury rzeczy, stąd też zwolennicy „rozwarstwiania” legalności na ,pierwotną” oraz „wtórną” określają je mianem ,pierwotnie legalnych”; w tym określeniu wyraz „legalne” ma oddawać to, że chodzi o zachowania się zgodne z prawem, a wyraz ,pierwotnie” - uwydatniać to, że chodzi o zachowania się nieprzekraczające normy sankcjonowanej. Dla odróżnienia na oznaczenie zachowań się kontratypowych używają oni określenia „,wtórnie legalne”, w którym wyraz ,legalne” ma podkreślać to samo co poprzednio, zaś wyraz ,wtórnie” — że chodzi jednak o zachowania się przekraczające normę sankcjonowaną, które „legalizuje” dopiero odpowiedni kontratyp. „Wtórnie” znaczy tu tyle i tylko tyle. Zwolennicy rozróżniania legalności pierwotnej oraz wtórnej wyraźnie odżegnują się od tego,

21 Tak wyraźnie na przykład K. Buchała, op. cit., s. 246; W. Patryas, Interpretacja karnistyczna. Studium metodologiczne, Poznań 1993, s. 30-31; W. Wróbel, Relacyjne i wartościujące ujęcie bezprawności w prawie karnym, RPEiS 1993, z. 3, s. 8; J. Majewski, Okoliczności wyłaczające bezprawność czynu, s. 51 n.; T. Kaczmarek, O tzw. okolicznościach ,wytaczających”..., s. 26-27. Sądzę, że do tej grupy wolno by też było zaliczyć W. Woltera, bo chyba w tym właśnie duchu należałoby „przekładać” poglądy tego autora wyrażane w języku, w którym terminu „norma prawna” się nie używa albo traktuje jako synonim terminu „przepis prawny”, na język niniejszej analizy.

22 Tak konsekwentnie w wielu swych pracach A. Zoll. Zob. zwłaszcza idem, Okoliczności wyłączajace bezprawność..., s. 121 n. Podobnie na przykład K. Indecki, A. Liszewska, Prawo karne materialne. Nauka o przestępstwie, karze i środkach penalnych, Warszawa 2002, s. 85. 
jakoby uważali zachowania się, które określają mianem „wtórnie legalnych”, za „pierwotnie" bezprawne ${ }^{23}$.

V. Przypomniawszy sobie, na czym polega istota założenia, że wśród zachowań się zgodnych z prawem jedne są „legalne pierwotnie”, a inne „legalne wtórnie", a także kiedy i w jakim celu idea owego podziału bywa przywoływana w ramach analizy karnistycznej, sprawdźmy, jak owo założenie ma się do podstawowych założeń dotyczących procesów tworzenia i stosowania prawa oraz jego analizy systematycznej, przyjmowanych w naszej kulturze prawnej, w szczególności czy się ono z tamtymi nie kłóci ${ }^{24}$.

Wśród założeń dotyczących procesów tworzenia i stosowania prawa oraz jego analizy systematycznej, przyjmowanych w naszej kulturze prawnej, niewątpliwie fundamentalną rolę odgrywa założenie idealizacyjne, że prawodawca jest pod każdym względem (doskonale) racjonalny, tj. cechuje się racjonalnością językową, socjotechniczną, prakseologiczną, aksjologiczną itp. ${ }^{25}$ Aksjomat, że prawodawca jest racjonalny, składa się z całego szeregu szczegółowych założeń modelujących, które dotyczą wiedzy i ocen owego konstruktu myślowego, jakim jest prawodawca racjonalny, a także warunków działalności prawotwórczej ${ }^{26}$. W obrębie założeń należących do ostatnio wymienionej grupy bardzo ważne miejsce zajmuje w szczególności założenie, że jeżeli prawodawca ustanawia normę nakazującą urzeczywistnić określony stan rzeczy, to tym samym chce, ażeby ów stan rzeczy powstał; „to, że norma obowiązuje, znaczyć ma, że prawodawca chce, by była ona

23 Por. A. Zoll, [w:] Kodeks karny. Część ogólna, t. 1, s. 536, teza 8 uwag wprowadzających do rozdz. III: „W wypadku kontratypów mamy do czynienia z wyłączeniem »wtórnym« bezprawności, co oczywiście nie oznacza traktowania kontratypów jako zachowań »pierwotnie« bezprawnych". Trzeba dodać, że cytowana deklaracja A. Zolla jest odpowiedzią na zarzut podniesiony przez Jubilata (T. Kaczmarek, O bezprawności i strukturze przestępstwa (wokót książki Zbigniewa Jędrzejewskiego), PiP 2010, z. 7, s. 93).

${ }^{24} \mathrm{~W}$ dużej mierze opieram się tu na analizie, którą przeprowadziłem w monografii poświęconej problematyce „kolizji obowiązków”. Zob. J. Majewski, Tak zwana kolizja obowiązków w prawie karnym, Warszawa 2002, passim, zwłaszcza s. 102-114.

${ }^{25}$ Zob. więcej L. Nowak, Próba metodologicznej charakterystyki prawoznawstwa, Poznań 1968, s. 80 n. L. Leszczyński zwraca uwagę, że założenie o racjonalności prawodawcy (jako podmiotu idealnego) jest do pewnego stopnia wymienne z założeniem o racjonalności prawa (jako rezultatu procesu prawodawczego) oraz założeniem o racjonalności porządku prawnego (jako zbioru wszystkich reguł funkcjonujących w obrocie prawnym i stanowiących potencjalne podstawy normatywne podejmowania decyzji stosowania prawa (idem, Zagadnienia teorii stosowania prawa. Doktryna i tezy orzecznictwa, Kraków 2001, s. 35).

26 Próbę rekonstrukcji teorii modelowej należącej do „struktury głębokiej” dogmatyki prawa naszej kultury prawnej podjął L. Nowak w pracy Interpretacja prawnicza. Studium z metodologii prawoznawstwa, Warszawa 1973. „Teorii doskonałego prawodawcy”, bo takie właśnie miano nadał jej sam autor — podobnie zresztą jak żadnej innej teorii wykładni — nie można, naturalnie, utożsamiać z taką czy inną normatywną koncepcją wykładni. 
spełniana" 27 . Innymi słowy - system norm prawnych ma wyznaczać ich adresatom takie zachowania się, przez które można skutecznie zrealizować „,cel” (,wolę”, „intencję") prawodawcy, a mianowicie doprowadzić do zamierzonego przezeń „stanu spraw społecznych” ${ }^{28}$ czy więcej — stanu świata w ogólności ${ }^{29}$. Z ostatnim z wymienionych założeń, oddającym ,racjonalność prakseologiczną" prawodaw$\mathrm{cy}^{30}$, koresponduje powszechnie żywione przekonanie, że funkcją pragmatyczną norm prawnych, podobnie jak norm innego rodzaju czy w ogóle wszelkich dyrektyw, jest wpływanie na zachowania się ich adresatów ${ }^{31}$.

Nietrudno dostrzec, że idei wtórnej legalności zachowań się kontratypowych niepodobna uzgodnić ani z tak pojmowanym założeniem racjonalności prakseologicznej prawodawcy, ani z tak rozumianą funkcją pragmatyczną normy ${ }^{32}$. Jądrem tej idei jest wszak twierdzenie, że czyn kontratypowy stanowi legalne, więc dozwolone przekroczenie normy sankcjonowanej. Zatem programowo zakłada się tu, że w pewnych stanach faktycznych, mianowicie sytuacjach kontratypowych, jakkolwiek norma sankcjonowana znajduje zastosowanie (aktualizuje się), to jednak jej adresat nie ma obowiązku jej spełnić, a skoro tak, to w tym zakresie nie może ona pełnić żadnej funkcji motywacyjnej. W sytuacjach, o których mowa, norma wprawdzie, według propagatorów idei wtórnej legalności, obowiązuje, lecz wcale nie znaczy to, że prawodawca chce, by była ona w tych sytuacjach spełniana (w przeciwnym razie nie zezwalałby na jej przekroczenie).

Powszechnie wyróżniane okoliczności wyłączające bezprawność czynu nie stanowią kategorii pod każdym względem jednorodnej. W szczególności jedne z nich służą „wyłączaniu” bezprawności czynów, których spełnienie jest ich sprawcom nakazane przez prawo (na przykład kontratypy: działania w granicach obowiązków służbowych oraz kolizji obowiązków), inne natomiast swym zakresem pokrywają czyny, których spełnienie nie jest ich sprawcom nakazane przez prawo (na przykład kontratypy: obrony koniecznej, dozwolonej krytyki, stanu wyższej konieczności) ${ }^{33}$. Nieusuwalne napięcie między ideą wtórnej legalności a założeniem racjonalności prakseologicznej prawodawcy oraz założeniem,

27 L. Nowak, Interpretacja prawnicza..., s. 33, 55.

28 Takiego określenia używa Z. Ziembiński (Logika praktyczna, Warszawa 1996, s. 231).

29 L. Nowak, Interpretacja prawnicza..., s. 33. Powoływany autor uważa wręcz, że w tym sensie „odtwarzanie woli prawodawcy” jest „naczelnym zadaniem” dogmatyki prawa.

30 Por. Z. Ziembiński, Problemy podstawowe prawoznawstwa, Warszawa 1980, s. 272.

31 Zob. więcej K. Opałek, Z teorii dyrektyw i norm, Warszawa 1974, s. 88 n., s. 178 n; idem, Argumenty za nielingwistyczna koncepcja normy. Uwagi dyskusyjne, SP 1988, nr 3-4, s. 208 n.; M. Zieliński, Z. Ziembiński, Dyrektywy i sposób ich wypowiadania, Warszawa 1993, s. 16 n. Por. K. Świrydowicz et al., O nieporozumieniach dotyczacych tzw. norm zezwalajacych, PiP 1975, z. 7, s. 57-58; F. Studnicki, Wyktadnia prawa w jej aspekcie komputacyjnym, SF 1985, nr 2-3, s. 101; T. Gizbert-Studnicki, Język prawny z perspektywy socjolingwistycznej, Kraków 1986, s. 15 n.

32 Por. J. Majewski, Okoliczności wytaczające bezprawność czynu, s. 68-69.

33 Por. ibidem, s. 51-52. 
że funkcją pragmatyczną norm prawnych jest wpływanie na zachowania się ich adresatów, szczególnie razi w obrębie pierwszej z wymienionych podkategorii kontratypów. Spójrzmy bowiem, jak w świetle założenia o wtórnej legalności zachowań się kontratypowych przedstawia się położenie podmiotu działającego w ramach kontratypu, który „wyłącza” bezprawność czynów nakazanych przez prawo. Otóż według zwolenników analizowanego założenia w takim wypadku aktualizują się wobec niego jednocześnie dwie normy sankcjonowane, których niepodobna naraz spełnić, gdyż wyznaczają one wzajemnie się wykluczające zachowania się, mianowicie norma zawarta w przepisie typizującym oraz norma sankcjonowana, nakazująca wykonanie czynu kontratypowego. Spełnienie obu norm jest obiektywnie niemożliwe, a cokolwiek ich adresat uczyni, przekroczy co najmniej jedną z nich. Jeżeli wykona czyn kontratypowy, spełni normę, która to nakazuje, lecz zarazem przekroczy normę zawartą w przepisie typizującym, będzie to wprawdzie przekroczenie usprawiedliwione, lecz jednak przekroczenie; z kolei jeżeli nie wykona czynu kontratypowego, może zastosować się do drugiej z tych norm, lecz przekroczy pierwszą... Wróćmy do przykładu funkcjonariusza policji, który w toku wykonywania obowiązków służbowych zatrzymuje sprawcę na gorącym uczynku kradzieży z włamaniem. Kto uważa zachowania się kontratypowe za wtórnie legalne, ten powie, że policjant, wykonując swój obowiązek służbowy, a więc spełniając normę, która ów obowiązek wyznacza, przekroczył normę zakazującą pozbawiania człowieka wolności, zawartą w art. 189 k.k. Widać jak na dłoni, że u podstaw kwalifikowania czynów kontratypowych jako wtórnie legalnych w obrębie rozpatrywanej kategorii kontratypów, tj. kontratypów, które „wyłączają" bezprawność czynów nakazanych przez prawo, leży przekonanie, że sprawcy takich czynów znajdują się w sytuacji, którą w piśmiennictwie karnistycznym określa się najczęściej mianem „kolizji obowiązków (prawnych)”34. To zaś oznacza, że koniecznym składnikiem idei wtórnej legalności jest założenie, iż w obrębie systemu prawa istnieją normy sankcjonowane, które pozostają względem siebie w takiej relacji, że przynajmniej w niektórych okolicznościach wypełnienie ich wszystkich zarazem nie jest możliwe, czyli normy formalnie ze sobą niezgodne ${ }^{35}$. Rzeczonego założenia niepodobna wszakże pogodzić z fundamen-

34 Więcej zob. J. Majewski, Tak zwana kolizja obowiazków.... Zob. też recenzję tej pracy ogłoszoną przez J. Giezka (Recenzja rozprawy J. Majewskiego „Tak zwana kolizja obowiazków w prawie karnym”, KPP 2003, nr 1, s. 251 n.) oraz moją na nią odpowiedź (Recenzentowi w odpowiedzi, KPP 2003, nr 2, s. 227 n.).

35 Por. J. Majewski, Tak zwana kolizja obowiązków..., s. 91 n. Gdy chodzi o rozważane zagadnienie, nie ma dotąd konwencji terminologicznej, która byłaby powszechnie akceptowana i stosowana. Skorzystam tu z siatki pojęciowej wypracowanej w poznańskim ośrodku teorii prawa. Więcej o formalnej niezgodności norm zob. na przykład Z. Ziembiński, O rodzajach niezgodności norm, SF 1969, nr 1, s. 91-92; M. Piotrowski, O rodzajach niezgodności norm, SF 1978, nr 11, s. 98-100. Od niezgodności norm formalnej odróżniać trzeba niezgodność prakseologiczną, kiedy wypełnienie jednej z branych pod uwagę norm co najmniej częściowo niweczy lub zaprzepaszcza 
tami powszechnie zakładanej idei prawa jako systemu, a więc zbioru elementów uporządkowanych w określony sposób i w określonym stopniu ${ }^{36}$.

System prawa jako zbiór obowiązujących w danym miejscu i czasie norm prawnych $^{37}$ ma charakteryzować się pewnymi cechami formalnymi. W szczególności zgodnie nakłada się nań warunek wewnętrznej spójności (określanej też jako „niesprzeczność”, ,jedność” itp.) ${ }^{38}$, który jest spełniony tylko wówczas, gdy dany system prawa nie zawiera norm ze sobą niezgodnych. Minimum minimorum pod tym względem stanowi brak niezgodności formalnych między normami ${ }^{39}$. Spójność w tej sferze jest wręcz postrzegana jako podstawowa, elementarna cecha systemu prawa ${ }^{40}$, a odpowiednio jej brak — jako rażąca wada, którą jak najrychlej należy przezwyciężyć za pomocą odpowiednich środków ${ }^{41}$. Postulat spójności systemu prawa bywa uzasadniany w różny sposób (znaczenia różnic w tym zakresie

skutki osiągnięte dzięki zrealizowaniu innej. Więcej o tym typie niezgodności norm zob. na przykład Z. Ziembiński, Problemy podstawowe prawoznawstwa, s. 225-226; M. Piotrowski, op. cit., s. 100-102. Gwoli ścisłości warto jednak odnotować, że w wielu opracowaniach z zakresu teorii prawa terminu „,niezgodność norm” (lub jemu podobnych) używa się w znaczeniu węższym niż tu, nieobejmującym konfliktów norm o charakterze prakseologicznym. Por. na przykład L. Nowak, Interpretacja prawnicza..., s. 76-78; J. Nowacki, Z. Tobor, Wstep do prawoznawstwa, Warszawa 1993, s. 152 oraz powołane tam piśmiennictwo.

36 Por. J. Majewski, Tak zwana kolizja obowiazków..., s. 141; idem, Okoliczności wyłaczające bezprawność czynu, s. 65-66. Trafnie zwraca na to uwagę również Jubilat (T. Kaczmarek, O tzw. okolicznościach ,wyłaczających”..., s. 27).

37 Kwestia, z jakich elementów składa się system prawa, jest sporna, a w każdym razie nie do końca wyjaśniona. Dowodzi się również na przykład, że system prawa to zbiór aktów prawnych albo że system prawa to zbiór przepisów zawartych w aktach normatywnych. Jest to, przynajmniej do pewnego stopnia, sprawa wyboru określonej konwencji terminologicznej. Uważam, że przyjęty tu przeze mnie sposób definiowania systemu prawa jako zbioru norm prawnych najlepiej współgra z wcześniej wprowadzonym fundamentalnym założeniem o potrzebie (konieczności) rozróżniania przepisów oraz norm prawnych.

38 „Spójność systemu prawnego jako jego postulowana cecha nie budzi żadnych wątpliwości” — jak zauważa J. Wróblewski (Recenzja: Les Antinomies en Droit. Etudes publiées par Ch. Perelman. Travaux du Centre National Recherches de Logique, Bruxelles 1965, PiP 1966, z. 12, s. 944).

39 Wypadki występowania w systemie prawa niezgodności prakseologicznych między normami ocenia się zwykle łagodniej. Por. następującą wypowiedź Z. Ziembińskiego: „Nasuwa się refleksja, że spójność formalna norm systemu, brak niezgodności formalnej, jest wymogiem podstawowym, którego naruszenie jest czymś, co jest bardziej rażące jako brak racjonalności, czymś, co w większym stopniu naraża dany system norm na krytykę, przynajmniej ze strony prawników, podczas gdy brak spójności prakseologicznej, choć niejednokrotnie jest wadą systemu mającą większą doniosłość społeczną, może być sprawą dyskusyjną i kwestionowany będzie raczej przez polityków, niż przez prawników, zwłaszcza prawników nastawionych formalistycznie, a nie socjotechnicznie" (idem, Problemy podstawowe prawoznawstwa, s. 226-227).

40 Por. S. Wronkowska [w:] A. Redelbach, S. Wronkowska, Z. Ziembiński, Zarys teorii państwa i prawa, Warszawa 1994, s. 220.

${ }^{41}$ Por. na przykład następującą uwagę R. Sarkowicza: „Naruszenie spójności formalnej systemu jest rażącym błędem, który winno się niezwłocznie eliminować za pomocą odpowiednich reguł kolizyjnych" ([w:] R. Sarkowicz, J. Stelmach, Teoria prawa, Kraków 1996, s. 158). 
nie należy wszakże przeceniać, gdyż, jak się zdaje, poszczególne uzasadnienia nie wyłączają się wzajemnie, mają względem siebie charakter poniekąd komplemenarny). W szczególności dowodzi się, że „system zawierający normy niezgodne formalnie byłby niezdolny do kierowania ludzkimi zachowaniami i z tego względu byłby [...] rażąco nieracjonalny"42; wskazuje, że brak niezgodności w prawie jest jednym z warunków tak czy inaczej pojmowanej jego skuteczności ${ }^{43}$; podnosi, że prawo zawierające normy formalnie niezgodne byłoby niegodziwe czy niemoralne ${ }^{44}$; zakłada niesprzeczność systemu prawa jako postulat poznawczy prawoznawstwa $^{45}$ itp. Jakkolwiek podawane jej uzasadnienia nie są jednakowe, sama teza, że system prawny powinien być formalnie spójny wewnętrznie - warto to powtórzyć - cieszy się w doktrynie i praktyce prawniczej powszechnym uznaniem.

Niezależnie [...] od przyjęcia takiego czy innego uzasadnienia lub wyjaśnienia niesprzeczności, które zależy od przyjętej teorii prawa i płaszczyzny badań, na której tę niesprzeczność się analizuje - piszą K. Opałek i J. Wróblewski — niezaprzeczalnym faktem jest to, że w procesach tworzenia, stosowania i analizy systematycznej systemów prawa dąży się do tego, by normy obowiązujące stanowiły niesprzeczną [...] całośćc ${ }^{46}$.

Założenie, że system prawa nie może zawierać norm, które byłyby formalnie niezgodne z innymi normami należącymi do tego systemu, jest szczególnie eksponowane w ramach tych uzasadnień zasady formalnej spójności systemu prawa, które odwołują się do idei racjonalnego prawodawcy. Racjonalny prawodawca nie ustanawia norm, które nie nadają się do kierowania postępowaniem podmiotów podległych danemu systemowi prawa. Takimi zaś byłyby w szczególności normy nakazujące czynienie rzeczy niemożliwych oraz normy niezgodne formalnie z innymi normami. Tak, jak uchybiałoby postulatowi racjonalności prawodawcy przyjęcie, że chciałby on spełniania normy, która wyznacza swym adresatom zachowania się niemożliwe ${ }^{47}$, tak też racjonalny prawodawca nie może chcieć, by były spełniane normy formalnie niezgodne, albowiem chciałby wówczas czegoś, czego jednocześnie uczynić właśnie niepodobna; co najmniej jedna z tych norm nie mogłaby pełnić żadnej funkcji sugestywnej — z góry wszak byłoby wiadomo, że wszystkie te normy nie oddziałają zarazem w pożądanym kierunku. $\mathrm{Z}$ tych to względów „założenie prakseologicznej racjonalności »prawodawcy« każe przy-

42 S. Wronkowska, op. cit., s. 220.

43 Tak na przykład K. Opałek, J. Wróblewski, Zagadnienia teorii prawa, Warszawa 1969, s. $104-105$.

44 Dla L.L. Fullera na przykład to, by prawo nie wymagało niemożliwego, jest postulatem wewnętrznej moralności prawa (The Morality of Law, New Haven-London 1964, s. 70 n.).

45 Tak na przykład Kelsenowski normatywizm.

46 K. Opałek i J. Wróblewski, op. cit., s. 106.

47 Por. L. Nowak, Interpretacja prawnicza..., s. 58 n.; Z. Ziembiński, Problemy podstawowe prawoznawstwa, s. 132-133; M. Zieliński, Z. Ziembiński, Uzasadnianie twierdzeń, ocen i norm w prawoznawstwie, Warszawa 1988, s. 58-59. 
jąć, iż przepisy, które ustanawia, nie formułują norm między sobą wzajemnie niezgodnych"48. Założenie, iż jeżeli jakaś norma obowiązuje, to prawodawca chce, by była ona spełniania, należy do grupy najmocniejszych założeń szczegółowych składających się na model racjonalnego prawodawcy, w każdym razie o tyle, o ile uzasadnia tezę, że system prawa nie może zawierać norm formalnie niezgodnych.

Jeśli niekiedy uchyla się założenie racjonalności „prawodawcy” w zakresie posługiwania się językiem, dopuszczając możliwość, że „prawodawca źle się wyraził” — podkreśla Z. Ziembiński - to nie dopuszcza się myśli, by „prawodawca” ustanawiał i uznawał za nadal obowiązujące normy między sobą sprzeczne lub sobie przeciwne ${ }^{49}$.

Gdybyśmy zgodzili się na obowiązywanie w obrębie systemu prawa chociażby dwóch norm formalnie między sobą niezgodnych, mielibyśmy do czynienia z wadą w pewnym sensie systemową, albowiem cały ów system stałby się sprzeczny. Byłaby to zarazem wada bardzo poważna, gdyż system sprzeczny, jak wiadomo, nie wyznacza żadnego postulowanego modelu. Ściśle biorąc — sprzeczne prawo niczego by nie normowało, a w związku z tym było całkowicie niezdatne jako narzędzie mające służyć zbliżaniu świata realnego do świata postulowanego, tj. zamierzonego przez prawodawcę ${ }^{50}$. Ale nawet przy mniej rygorystycznym (a bardziej realistycznym) podejściu, zakładającym, że spójność systemu prawa, w tym także spójność formalna, jest cechą stopniowalną, systemowe konsekwencje tej wady byłyby bardzo doniosłe. Wszelkie przejawy niezgodności norm występujące w obrębie systemu prawnego — zarówno niezgodności formalnej, jak i prakseologicznej — podrywają prestiż prawa, osłabiają jego oddziaływanie sugestywne; $i$ to na wszystkich poziomach, a nie jedynie w tym zakresie, w jakim wyznacza ono podległym mu podmiotom powinności naraz niemożliwe do spełnienia albo nakazuje im spełnianie czynów, których skutki nawzajem się niweczą ${ }^{51}$.

VI. Jak wynika z przedstawionej analizy — zwolennik założenia, iż zachowania się kontratypowe są wtórnie legalne, to znaczy stanowią zgodne z prawem przekroczenie normy sankcjonowanej, dbały o wewnętrzną spójność wyznawanych poglądów, powinien w istotnym zakresie zrewidować podstawowe założenia dotyczące procesów tworzenia i stosowania prawa oraz jego analizy systematycznej, przyjmowane w naszej kulturze prawnej. Mianowicie, powinien odrzucić bar-

48 Z. Ziembiński [w:] A. Redelbach, S. Wronkowska, Z. Ziembiński, op. cit., s. 214.

49 Z. Ziembiński, Logika praktyczna, s. 241. Sądzić należy, że autor ma tu na myśli wyłącznie niezgodność formalną norm, gdyż gdzie indziej wyraźnie zaznacza, że „można niekiedy tolerować mniej jaskrawą niezgodność prakseologiczną norm systemu" (Problemy podstawowe prawoznawstwa, s. 273). Por. też W. Lang, L. Morawski, T. Gawrysiak, Koncepcja „prawodawcy doskonatego" i jej zastosowanie w prawoznawstwie. Próba krytycznej analizy książki L. Nowaka Interpretacja prawnicza, PiP 1976, z. 1-2, s. 129 n.

50 Por. J. Woleński, Logiczne problemy wykładni prawa, Kraków 1972, s. 59-60.

51 Por. Z. Ziembiński, Problemy podstawowe prawoznawstwa, s. 274. 
dzo istotny składnik modelu racjonalności prawodawcy, określający jądro aspektu prakseologicznego tego modelu, jakim jest założenie, że normy prawne ustanawia się po to, by były spełniane, a także wszelkie wynikające $\mathrm{z}$ niego konsekwencje, w tym założenie, że nie ustanawia się norm niezgodnych formalnie z innymi normami ani żadnych innych norm, które nie nadają się do kierowania postępowaniem podmiotów podległych danemu systemowi prawa; powinien też odstąpić od ujmowania obowiązującego prawa jako zbioru norm prawnych, które tworzą system, a to ze względu na niespełnianie przez ów zbiór warunku wewnętrznej spójności. I jedno, i drugie posunięcie byłoby nadzwyczaj ryzykowne, albowiem nie wolno zapominać o tym, że założenie idealizacyjne, iż prawodawca jest pod każdym względem racjonalny, ułatwia, a być może w ogóle umożliwia prawnikom konstruowanie systemu prawnego w oparciu o zakładane fakty prawotwórcze ${ }^{52}$, uprawomocniając reguły, którymi w tym procesie się kierują (w szczególności reguły interpretacyjne, inferencyjne oraz kolizyjne). $Z$ kolei powszechnie aprobowany postulat niesprzeczności prawa, chociaż w różny sposób uzasadniany, w ramach każdego z przyjmowanych uzasadnień jest uważany za wykładnik bardzo istotnych wartości: moralnych, poznawczych, użytkowych itp.

Koszta, jakie trzeba by ponieść za odwoływanie się do idei wtórnej legalności w ramach pewnego spójnego zespołu twierdzeń, byłyby więc ogromne, a trzeba pamiętać, że chodzi o szacunek bardzo zgrubny i tylko częściowy, albowiem mówiliśmy dotąd wyłącznie o kosztach, powiedzmy, najbardziej bezpośrednich. W istocie rewizji i przemodelowania wymagałoby wiele innych składników naszej kultury prawnej, które w takim lub innym stopniu są skorelowane z założeniem racjonalności prakseologicznej prawodawcy oraz postulatem wewnętrznej spójności prawa. Na przykład założenie, że system prawa nie może zawierać norm formalnie niezgodnych znajduje odpowiednie odzwierciedlenie w ukształtowaniu jego, tak zwanych, reguł konstrukcji. Ochrona spójności formalnej systemu prawa jest główną racją istnienia pewnej grupy reguł egzegezy tekstu prawnego, określanych mianem „,reguł kolizyjnych”53. Ich zadaniem jest zagwarantowanie, by wszelkie formalne niezgodności norm pozostały jedynie niezgodnościami prima facie, a więc z punktu widzenia rekonstrukcji systemu norm prawnych pojmowanej wynikowo — niezgodnościami w istocie tylko pozornymi. Zresztą, właściwie cały proces egzegezy tekstu prawnego - by użyć tu za Z. Ziembińskim terminu zbiorczego dla ogółu zabiegów związanych z „opracowywaniem tekstu prawnego" 54 — jest tak

52 Por. L. Nowak, Próba metodologicznej charakterystyki prawoznawstwa, s. 72-75.

53 Więcej o tych regułach zob. K. Ziemski, Rola i miejsce regut kolizyjnych w procesie dekodowania teksu prawnego, RPEiS 1978, z. 2, s. 1 n. Osobną sprawą jest to, że termin „,reguła kolizyjna" jest w języku prawniczym wyrażeniem nader wieloznacznym (por. M. Zieliński, Z. Ziembiński, Uzasadnianie..., s. 223).

54 To jest (re)konstruowaniem systemu norm prawnych na podstawie tekstu prawnego przy użyciu reguł interpretacyjnych, inferencyjnych oraz kolizyjnych, zwanych łącznie właśnie regułami egzegezy. 
zorientowany, by zapobiegać uzyskiwaniu norm formalnie między sobą niezgodnych. W szczególności także w obrębie reguł interpretowania tekstów prawnych wyróżnić można dyrektywy służące temu właśnie celowi. Nakazują one odrzucić określony wynik wykładni, jeśli miałby on pociągać za sobą zaliczenie do systemu norm formalnie między sobą niezgodnych ${ }^{55}$. Nierzadko mówi się wprost o dwóch drogach usuwania niezgodności norm: jednej związanej z użyciem reguł kolizyjnych dotyczących obowiązywania norm oraz drugiej — , interpretacyjnej”56.

VII. Wolno mieć wątpliwości, czy zwolennicy dzielenia zachowań się zgodnych z prawem na „legalne pierwotnie” oraz „legalne wtórnie” są w pełni świadomi ceny, jaką należałoby zapłacić za odwoływanie się do idei wtórnej legalności w ramach pewnego spójnego wewnętrznie zespołu twierdzeń. W każdym razie bynajmniej nie odrzucają oni założenia, że normy prawne ustanawia się po to, by były one spełniane (racjonalność prakseologiczna prawodawcy) ani korespondującego z nim założenia, że funkcją pragmatyczną normy prawnej jest wpływanie na postępowanie jej adresatów; przeciwnie — w swych analizach bardzo chętnie odwołują się do tych założeń. Podkreślają oni, że normy prawne prawodawca „wydaje [...] po to, by motywować zachowanie ludzkie w kierunku pozytywnie przez ustawodawcę ocenianym"; że norma prawna w aspekcie teleologicznym wyraża „wolę ustawodawcy, aby adresaci normy postępowali w określony sposób”, stanowi „polecenie”, „żąda określonego zachowania się" "57. Jakby w ogóle nie dostrzegali, że w sytuacjach kontratypowych norma sankcjonowana nie może pełnić żadnej funkcji motywacyjnej, skoro nie ma się w nich obowiązku jej przestrzegać. Chciałoby się dowiedzieć od zwolenników dzielenia zachowań się zgodnych z prawem na „legalne pierwotnie” oraz „legalne wtórnie”, jakiż ich zdaniem miałby być sens obowiązywania normy sankcjonowanej także w sytuacjach tego rodzaju, jakiż cel objęcia tych sytuacji jej zakresem i jakąż funkcję miałaby tu pełnić ta norma. Niestety, w ich pracach próżno by szukać przekonywającej odpowiedzi na tak postawione pytania...

Z kolizją między ideą wtórnej legalności a założeniem, że system prawa nie powinien zawierać norm formalnie ze sobą niezgodnych, sprawa przedstawia się inaczej. Istnienie takiej kolizji zwolennicy ujmowania zachowań się kontratypowych jako zgodnego z prawem przekroczenia normy sankcjonowanej próbują negować, podnosząc, że z postulatem niesprzeczności prawa kłócą się jedynie całkowita sprzeczność oraz całkowite przeciwieństwo norm, a w niczym nie uchybia mu niezgodność częściowa, z którą mamy do czynienia w sytuacjach kontraty-

55 Dyrektywy interpretacyjne, o których tu mowa, są różnie klasyfikowane: przez jednych do kategorii dyrektyw językowych, przez innych znowu do osobnej kategorii dyrektyw systemowych.

56 Por. na przykład K. Opałek i J. Wróblewski, op. cit., s. 100, 248.

57 Por. na przykład A. Zoll, O normie z punktu widzenia..., s. 75 n.; cytowane określenia zaczerpnąłem ze s. 76 i 78. 
powych $^{58}$. Ostatnio wymieniony przejaw niezgodności norm ma być, ich zdaniem, nieszkodliwy dla idei wewnętrznej spójności systemu prawa. Wskazują oni w szczególności, że:

częściowa niezgodność norm [...] nie jest chyba przejawem formalnej niespójności prawa, a już z całą pewnością nie oznacza braku racjonalności ustawodawcy, tworzącego normy wzajemnie sprzeczne (lub przeciwstawne), które nie nadają się do kierowania postępowaniem podmiotów podległych danemu systemowi prawa,

\section{jako że prawodawca}

nie może być oceniony jako nieracjonalny z tego tylko powodu, że tworzy normy, które in concreto, tzn. na etapie stosowania prawa, mogą wzajemnie kolidować, lecz zasługuje na taką ocenę dopiero wówczas, gdy ustanawia normy, które na płaszczyźnie ustawowej, tzn. już na etapie tworzenia prawa in abstracto ze sobą kolidują;

jeżeli na przykład — powiadają — „obowiązuje norma »ratuj życie«, a w konkretnej sytuacji zagrożone jest życie dwóch osób jednocześnie, to adresat takiej normy staje przed obowiązkiem uratowania każdej z nich" także wówczas, gdy jest to „ze względu na szczególne okoliczności danej sytuacji [...] niemożliwe"59.

W innym miejscu starałem się wykazać nieskuteczność tej obrony, w szczególności nierelewantność rozróżniania sprzeczności (przeciwieństw) norm: „całkowitych” i „częściowych” oraz ,abstrakcyjnych” i „konkretnych” z punktu widzenia wymogu wewnętrznej spójności systemu prawa ${ }^{60}$. Tu przypomnę jedynie, że kiedy w piśmiennictwie teoretycznoprawnym podkreśla się, że system prawa zawierający normy formalnie ze sobą niezgodne byłby rażąco wadliwy, nie ogranicza się tej oceny wyłącznie do zjawiska całkowitej niezgodności norm, lecz odnosi ją w równej mierze do wszelkich przejawów formalnej niezgodności norm, w tym niezgodności częściowej.

Jak widać - zwolennicy ujmowania zachowań się kontratypowych jako zgodnego z prawem przekroczenia normy sankcjonowanej nie rezygnują wca-

58 Niezgodność „całkowita (radykalna)” norm zachodzi wówczas, gdy zakresy adresatów i zakresy zastosowania norm formalnie niezgodnych są zamienne (w całości się pokrywają), pozostałe przejawy formalnej niezgodności norm określa się mianem „niezgodności częściowej”. Na podobnej zasadzie wyróżnia się sprzeczność norm „całkowitą (radykalną)” i „częściową” oraz przeciwieństwo norm „całkowite (radykalne)” i „częściowe”.

59 J. Giezek, Recenzja rozprawy J. Majewskiego..., cytaty zaczerpnąłem ze s. 252 przypis 3, s. 265 przypis 14 oraz s. 256. Powoływana praca pochodzi z okresu, w którym J. Giezek wyraźnie sympatyzował z koncepcją wtórnej legalności zachowań się kontratypowych. Dla porządku dodać trzeba, że mowa o Autorze, który sam podkreśla, że „normy postępowania [...] spełniać muszą skierowaną ku przyszłości funkcję sterującą oraz określającą" (Przyczynowość oraz przypisanie skutku w prawie karnym, Wrocław 1994, s. 69), a zatem akceptuje powszechnie żywione przekonanie, że funkcją pragmatyczną wszelkich norm postępowania, a w szczególności norm prawnych, jest wpływanie na zachowania się ich adresatów, że normy ustanawia się po to, aby były spełniane.

60 Zob. J. Majewski, Recenzentowi w odpowiedzi, s. 228-231. 
le z tych powszechnie przyjmowanych założeń dotyczących procesów tworzenia i stosowania prawa oraz jego analizy systematycznej, z którymi idei wtórnej legalności nie sposób uzgodnić. Wprawdzie unikają w ten sposób obciążenia głoszonych przez siebie poglądów ograniczeniami, jakie wymusza posługiwanie się ową ideą - części tych ograniczeń zdają się w ogóle nie dostrzegać, inne kwestionują - lecz zarazem płacą cenę nieporównanie wyższą. Jest nią wewnętrzna niespójność tychże poglądów.

VIII. Ani to, że zwolennicy idei wtórnej legalności unikają wzięcia na siebie kosztów posługiwania się tą kategorią, ani to, że koszty te przedstawiają się jako naprawdę niebagatelne, nie przesądza jeszcze automatycznie o tym, że na pewno nie warto byłoby tych kosztów ponieść. Może wartość pożytków, jakie przynosi albo przynajmniej mogłoby przynieść posługiwanie się kategorią wtórnej legalności, owe koszty przewyższa, co ostatecznie dawałoby ekspektatywę jakiegoś zysku i uzasadniało ich poniesienie? Sprawdźmy, jakież miałyby to być pożytki.

Zwolennicy tezy, że powinno się przyjmować, iż zachowania się kontratypowe są przekroczeniem właściwych norm sankcjonowanych ${ }^{61}$, na płaszczyźnie teoretycznej przedstawiają na jej poparcie rozmaicie ujmowane argumenty ${ }^{62}$. W szczególności podnoszą oni, że:

1) z punktu widzenia materialnej istoty przestępstwa zachowania się kontratypowe nie różnią się niczym od zachowań się niekontratypowych skierowanych przeciwko danemu dobru prawnemu — tak samo jak te drugie są społecznie szkodliwe, choć stoi za nimi ostatecznie „dodatni bilans zysków i strat”63;

2) zachowanie się kontratypowe - inaczej niż zachowanie się w ogóle niegodzące w dobro prawne, którego ochrona jest racją ustanowienia odpowiedniej normy sankcjonowanej, oraz zachowanie się nienaruszające reguł postępowania z tym dobrem — niweczy cel ustanowienia odpowiedniej normy sankcjonowanej w takim samym stopniu jak przekraczające tę normę zachowania się niekontratypowe i jest tak samo jak one negatywnie wartościowane ${ }^{64}$;

61 Nie chodzi tu tylko o zwolenników kwalifikowania zachowań się kontratypowych jako wtórnie legalnych, lecz także o zwolenników kwalifikowania ich jako bezprawnych, lecz niekaralnych.

$62 \mathrm{~W}$ znakomitej większości są to argumenty zaczerpnięte od A. Zolla, czego nie ukrywają. Tak na przykład M. Bielski (Koncepcja kontratypów jako okoliczności wyłączających karalność, CPKiNP 2010, z. 2, s. 41) wyraźnie podkreśla, że jego ujęcie „nawiązuje bardzo mocno do koncepcji kontratypów wypracowanej przez Andrzeja Zolla.

63 Por. A. Zoll, Okoliczności wytączające bezprawność..., s. 85 n.; podobnie Ł. Pohl, Struktura normy sankcjonowanej w prawie karnym. Zagadnienia ogólne, Poznań 2007, s. 181-183; M. Bielski, op. cit., s. 44 i 48.

64 Por. M. Bielski, op. cit., s. 32: „Zabicie człowieka w obronie koniecznej, z punktu widzenia normy sankcjonowanej możliwej do odtworzenia z art. 148 k.k., jest tak samo negatywnie wartościowane, jak zabicie człowieka dla pieniędzy". 
3) w przeciwnym wypadku doszłoby do zrównania konsekwencji zachowań się kontratypowych z zachowaniami się w ogóle niegodzącymi w dobro prawne, którego ochrona jest racją ustanowienia odpowiedniej normy sankcjonowanej, oraz zachowaniami się nienaruszającymi reguł postępowania z tym dobrem ${ }^{65}$, a w wypadku tych ostatnich „brak bezprawności czynu wynika [...] z braku negatywnej oceny"66;

4) zachowanie się kontratypowe stanowi typowy atak na dobro prawne z punktu widzenia celu normy sankcjonowanej zorientowanej na ochronę tego dobra ${ }^{67}$;

5) kolizja dóbr, leżąca u podstaw zachowania się kontratypowego, ma charakter względny, przez co może być rozstrzygana tylko in concreto, a zawężenie zakresu zastosowania normy sankcjonowanej jest operacją dokonywaną in abstracto na poziomie generalno-abstrakcyjnym ${ }^{68}$.

Wymieniłem wyżej bodaj wszystkie najistotniejsze „pożytki”, jakie według promotorów kategorii wtórnej legalności ma przynosić posługiwanie się nią. Gdyby nawet a priori uznać trafność powołanych argumentów, to i tak niepodobna byłoby w tym wyliczeniu doszukać się pożytków tej wagi, która musiałaby wchodzić w grę, aby zrekompensować odejście od podstawowych założeń dotyczących procesów tworzenia i stosowania prawa oraz jego analizy systematycznej, przyjmowanych w naszej kulturze prawnej. Co więcej, kiedy tylko przystąpi się do krytycznej analizy owych argumentów, rychło wychodzi na jaw, że w rzeczywistości sprawa przedstawia się jeszcze gorzej.

Znakomita większość argumentów podawanych na poparcie twierdzenia, że powinno się przyjmować, iż zachowania się kontratypowe stanowią przekroczenie właściwych norm sankcjonowanych, w tym pierwsze cztery argumenty z podanego wyżej zestawienia, ściśle się ze sobą wiąże i w istocie obraca się wokół tego samego, jedynie różnie wyrażanego przekonania, że zachowania się kontratypowe stanowią społecznie szkodliwy, negatywnie wartościowany, a przez to typowy atak na dobro prawne. Tymczasem przekonanie to jest jawnie niespójne z kluczowym składnikiem idei wtórnej legalności zachowań się kontatypowych, wyjaśniającym, dlaczego zachowania się kontratypowe, mimo że stanowią przekroczenie normy sankcjonowanej, należy ostatecznie kwalifikować jako zgodne z prawem - mam na myśli twierdzenie, że za zachowaniami się kontratypowymi stoi „dodatni bilans zysków i strat”, który usprawiedliwia („legalizuje”) przekroczenie normy sankcjonowanej ${ }^{69}$. Jak zachowanie się, z którym wiąże się dodatni społeczny bilans zysków i strat, a więc zachowania się społecznie opłacalne, może być jednocześnie oceniane jako społecznie szkodliwe i negatywnie wartościowa-

65 Por. ibidem, s. 31-32.

66 Por. ibidem, s. 32.

67 Por. A. Zoll, O normie z punktu widzenia..., s. 90; M. Bielski, op. cit., s. 44, 47.

68 Por. M. Bielski, op. cit., s. 44.

69 Por. J. Majewski, Okoliczności wyłączające bezprawność czynu, s. 74-75. Nawiązuję w tym akapicie do argumentacji, którą tam przedstawiłem. 
ne? Przecież kategoria społecznej szkodliwości w rozważaniach o materialnym pierwiastku przestępstwa (karygodności) służy właśnie wyrażeniu całościowej, globalnej oceny danego czynu z punktu widzenia zakładanego systemu wartości, nie zaś jakieś oceny cząstkowej, aspektowej, na przykład dotyczącej relacji rozpatrywanego czynu do jednego tylko, wybranego dobra prawnego. Pomijam już to, że w świetle ocen społecznych wyjątkowo nieprzekonywająco brzmi twierdzenie, że zabicie człowieka w obronie koniecznej z punktu widzenia celu ustanowienia normy sankcjonowanej, zawartej w art. 148 k.k., jest tak samo negatywnie wartościowane, jak zabicie człowieka dla pieniędzy. Otóż właśnie nie jest negatywnie wartościowane, stąd też między innymi art. $25 \S 1 \mathrm{w}$ naszym kodeksie karnym i jego odpowiedniki w ustawach karnych wielu innych państw naszego kręgu kulturowego. W świetle obowiązującego systemu wartości to twierdzenie, że zachowanie się mieszczące się $\mathrm{w}$ granicach na przykład obrony koniecznej jest społecznie szkodliwe, nie zaś twierdzenie przeciwne, jawi się jako całkowicie nieintuicyjne. Gdyby rozważane argumenty prawidłowo odzwierciedlały funkcjonujące w społeczeństwie oceny aksjologiczne — żołnierzy, którzy, narażając własne życie w obronie ojczyzny, czynili wszystko, co było w ich mocy, aby zadać jak najwięcej strat armii najeźdźcy, nie czcilibyśmy jako bohaterów, lecz ich godne chwały czyny ledwie usprawiedliwiali jako „mniejsze zło"70. Podobnie razi swą nieadekwatnością twierdzenie, że zachowania się kontratypowe naruszają reguły postępowania $\mathrm{z}$ dobrem, którego ochrona jest racją ustanowienia odpowiedniej normy sankcjonowanej. Treść tych reguł, wykuwająca się w obrocie społecznym z wiedzy i doświadczenia życiowego, nie stanowi przecież prostej odpowiedzi na pytanie, jak najskuteczniej chronić określone dobro, lecz uwzględnia również określone rozstrzygnięcia aksjologiczne, w tym odnośnie do możliwych kolizji między określonymi dobrami (różnego albo tego samego rodzaju). Gdyby treść reguł postępowania $\mathrm{z}$ dobrem prawnym była ukierunkowana wyłącznie na jak najskuteczniejszą ochronę tego dobra, w miejsce reguły nakazującej jazdę samochodem z prędkością bezpieczną mielibyśmy bezwzględny zakaz używania pojazdów mechanicznych w ruchu drogowym, gdyż z całą pewnością z punktu widzenia ochrony życia i zdrowia uczestników ruchu drogowego ta druga reguła jest bardziej efektywna niż pierwsza... Zwolennicy idei wtórnej legalności chętnie powtarzają za $\mathrm{H}$. Welzlem, że dobra prawne nie są muzealnymi eksponatami, lecz częścią codziennego życia społecznego, co w sposób oczywisty naraża je na uszczerbek ${ }^{71}$, lecz trudno oprzeć się wrażeniu, że gdy wyznaczając granice zakresowe normy sankcjonowanej, obejmują nimi także sytuacje kontratypowe, traktują dobra prawne dokładnie tak, jakby właśnie były one takimi eksponatami.

${ }^{70}$ Nawiązuję tu do wypowiedzi A. Zolla; uważa on, że „kolizję norm sankcjonowanych” konstytuująca sytuację kontratypową należy „rozwiązywać” zgodnie z dyrektywą, która „,nakazuje wybór mniejszego zła" (idem, O normie z punktu widzenia prawa karnego, s. 90).

71 Por. na przykład ibidem, s. 79. 
Nie przekonuje też argument, jakoby zachowania się kontratypowe nie mogły leżeć poza zakresem zastosowania odpowiedniej normy sankcjonowanej, gdyż zawężenie zakresu zastosowania takiej normy jest operacją dokonywaną in abstracto (na poziomie generalno-abstrakcyjnym), a leżąca u podstaw tych zachowań się kolizja dóbr może być rozstrzygana wyłącznie in concreto. Gdyby istotnie było to przeszkodą w przeprowadzeniu zabiegu stosownego uadekwatnienia (zawężenia) granic zakresowych normy sankcjonowanej, to - wbrew temu, co a priori zakładają zwolennicy krytykowanego tu podejścia i co stanowi punkt wyjścia dla ich argumentacji - granice te musiałyby obejmować również zachowania się stwarzające zagrożenie dobra prawnego, którego ochrona jest racją ustanowienia owej normy, lecz nienaruszające przyjętych reguł postępowania z tym dobrem. Wszak zgodnie przyjmuje się, że o tym, czy dane zachowanie się jest zgodne z tymi regułami, czy nie, decydują (przynajmniej niekiedy) właśnie okoliczności konkretnego przypadku (ocena in concreto) ${ }^{72}$.

IX. W świetle przeprowadzonego wyżej wywodu odpowiedź na tytułowe pytanie, czy idea tak zwanej wtórnej legalności się broni, może być tylko jedna — nie broni się.

\section{Is the idea of so-called "secondary legality" defensible?}

\section{Summary}

The aim of the study is critical analysis of the idea of so-called "secondary legality" of an act used by some jurists to explain types of behaviour falling into the category of circumstances excluding lawlessness of an act (justification), namely to define the relation between such types of behaviour and the legal system as a whole, and the various sanctioned norms that are part of the system. First, the author examines the relation between the assumption that a type of behaviour which falls within the category of circumstances excluding lawlessness of an act constitutes a legal transgression of the sanctioned norm, and the basic assumptions made in the Polish legal culture concerning the process of creation and application of the law as well as its systematic analysis. He demonstrates that consistent use of the secondary legality category would require a considerable remodelling of these assumptions, above all, rejection of the assumption that legal norms are introduced to be met as well as all consequences stemming from this assumption as well as abandonment of the approach to the law as a set of legal norms that is internally cohesive. Next, the author analyses the internal aspects of the idea of secondary legality of an act. He demonstrates that it encompasses contradictory statements: on the one hand that justifiable behaviour constitutes socially harmful, negative and thus a typical attack on legal interest, and on the other hand that the social benefits ultimately outweigh losses in the case of justifiable behaviour. All the above justifies the author's final conclusion that the category of secondary legality of an act is not useful.

Keywords: justification, circumstances excluding lawlessness of an act, transgression of sanctioned norms, primary legality, secondary legality.

72 J. Majewski, Okoliczności wyłączające bezprawność czynu, s. 75. 